\title{
Epiphytic cyanobacterial diversity in the sub-Himalayan belt of Garhwal region of Uttarakhand, India
}

\author{
Mukesh Kumar ${ }^{\star}{ }^{\star}$, Rajan Kumar Gupta ${ }^{2}$, A. B. Bhatt ${ }^{3}$ and S. C. Tiwari ${ }^{3}$ \\ ${ }^{1}$ Department of Botany, Sahu Jain P.G. College, Najibabad-246763, Uttar Pradesh, India; 2Department of Botany, Pt LMS \\ Government P.G. Autonomous College, Rishikesh, Uttarakhand, India; ${ }^{3}$ Department of Botany, HNB Garhwal Central \\ University, Srinagar, Uttarakhand, India
}

\begin{abstract}
Cyanobacteria constitute the largest, most diverse and widely distributed group of prokaryotes that perform oxygenic photosynthesis. These are known to comprise a diverse flora of morphologically distinct forms. Some species are epiphytic occurring on a variety of plants. The present study was undertaken to study the distribution pattern of epiphytic cyanobacterial flora in the foot-hills of Garhwal Himalaya. An extensive survey was carried out in different seasons at four cyanobacteria-rich localities (Dakpatthar, Kotdwar, Rishikesh and Laldhang) of Uttarakhand state of India. A total of 39 epiphytic cyanobacterial taxa (12 heterocystous and 27 non-heterocystous) belonging to 2 orders, 7 families and 17 genera were recorded from this region. Highest number of species (25) was reported from Rishikesh, followed by Kotdwar with 14 species and Laldhang and Dakpatthar each with 12 species. Principal Component Analysis showed significant variation for epiphytic cyanobacterial diversity among studied sites, whereas cluster analysis categorized epiphytic cyanobacterial diversity under two categories, viz. Cluster I with 9 species and Cluster II with 30 species. Study concludes that variation in epiphytic cyanobacterial diversity might be compared to physicochemical properties of soil and climatic conditions along altitudes.

Key-words: Cyanobacteria, diversity, epiphytic, foot-Hill, Garhwal Himalaya.
\end{abstract}

\section{Introduction}

Cyanobacteria belong to the most archaic organisms on the earth. The palaeobotanical records show that they were first to appear on the globe for over 2.5 billion years ago (Schopf and Walter 1982; Schopf and Packer 1987) and dominated the biota in the Proterozoic Era, an Era between 2.5 and 0.5 billion years ago. Due to the occurrence of blue-green algae, the Proterozoic Era is also known as "Age of Cyanophyceae” (Van den Hoek et al. 1993). Cyanobacteria grow by the asexual mode of reproduction due to the formation of the hormogonia or endospores or by the fragmentation of the colonies. No sexual reproduction has been reported in cyanobacteria till

*For correspondence,

e-mail: mukesh.najibabad@gmail.com; tel: +919412518789 now. However, genetic recombination similar to bacteria has been observed in some cases (Kumar 1962).

They occur in great variety of natural habitats, but are often abundant in terrestrial and aquatic (freshwater and marine) environments. They exist in nature as free floating, epilithic, epipelic, epiphytic, endophytic and thermophilic forms (Fogg et al. 1973; Kumar 2002). Khare and Kumar (2009) have reported some Chroococcales growing as epiphytes in the foot-hills of Uttarakhand Himalaya. The members of Cyanophyceae also form dominant plant life in frigid rivers of Garhwal Himalaya, where they create an extensive benthic mat or scum under/over water ponds, streams and over the surface of moist soils. Ariosa et al. (2004) studied epiphytic cyanobacteria on Chara vulgaris and their role as main contributors to $\mathrm{N}_{2}$ fixation in rice fields. They proposed that average nitrogen fixation rate associated with 


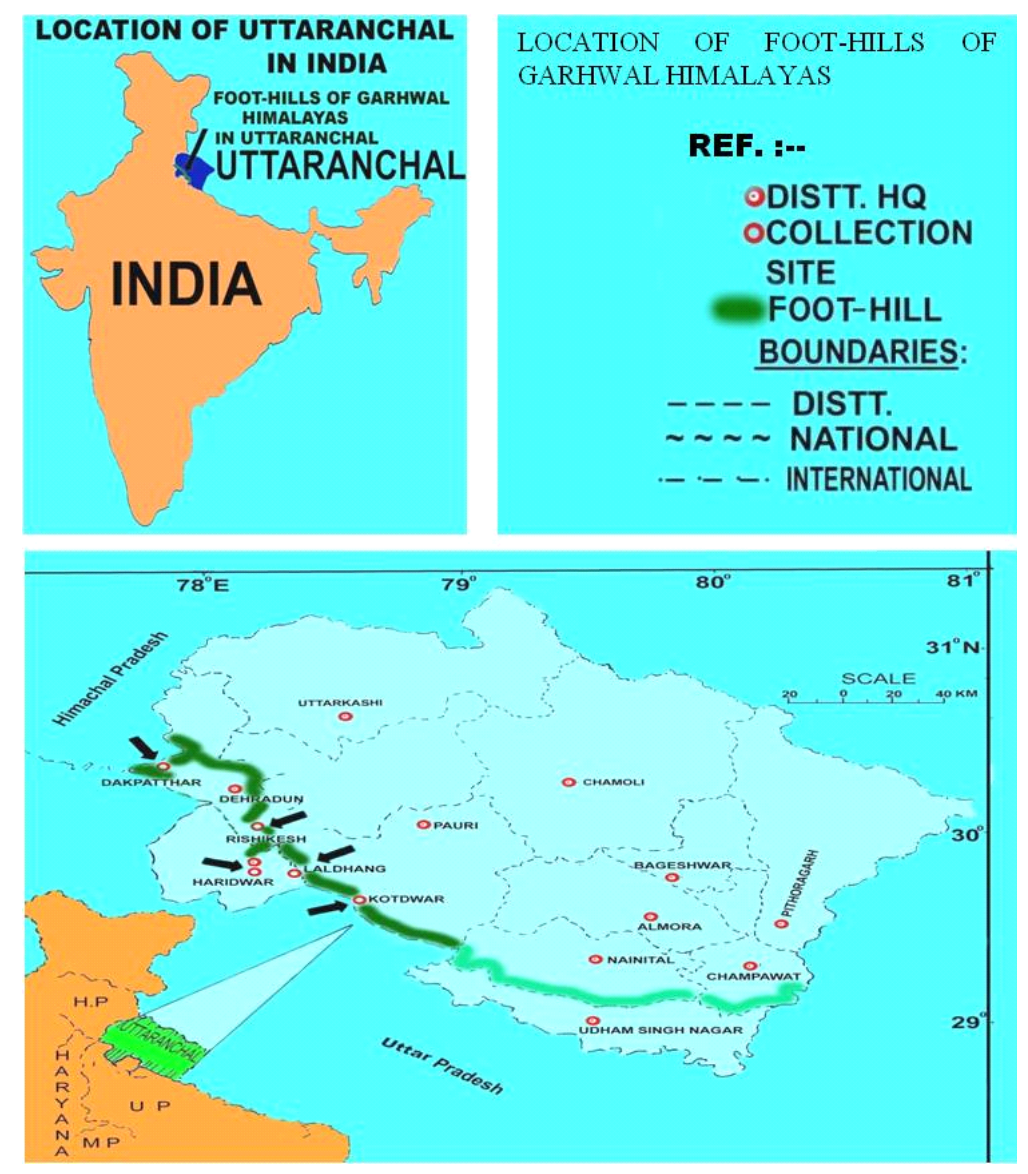

Figure 1. Location of the study sites (pointed by arrows) in the Garhwal Himalaya, Uttarakhand, India.

Chara was $27.53 \mathrm{~kg}$ of $\mathrm{N}$ ha"1 crop" ${ }^{1}$. Fong et al. (2006) studied epiphytic cyanobacteria and found that they maintain shifts to macro-algal dominance on coral reefs. Williams et al. (2007) found a novel epiphytic cyanobacterium associated with reservoirs affected by avian vacuolar myelinopathy.

The abilities of cyanobacteria to withstand adverse ecological conditions, their capacity to thrive well in hostile environments, and response to the onset of dry conditions have distinguished this group as pioneers of plant succession. The light plays an important regulatory role with regard to distribution and abundance of cyanobacteria. Most of the species of cyanobacteria are obligate phototropic. $\mathrm{pH}$ is an important factor that affect the growth of cyanobacteria. Good cyanobacterial growth needs an optimum $\mathrm{pH}>7$ of the medium and sometimes as high as 10 (Fogg et al. 1973). Temperature also plays an important role in stimulating the growth of cyanobacteria. Robarts and Zohary (1987) reported that cyanobacteria dominate generally at temperatures $>20^{\circ} \mathrm{C}$.
Sub-Himalayan regions of Uttarakhand represent a habitat with a wide environmental heterogeneity in terms of temperature, rainfall, humidity and light intensity. These varied climatic conditions support cyanobacteria of different growth forms. However, extensive work on epiphytic cyanobacteria has not been done in the region. The present study has therefore been undertaken to study the distribution of cyanobacterial forms growing as epiphytes on various plants.

\section{Materials and Methods}

\section{STUDY AREA}

The study area is situated in south-west to east of Siwalik range of Garhwal Himalaya, Uttarakhand, India. The present study involves four sites, i.e. Dakpatthar (west), Rishikesh, Laldhang and Kotdwar (south-west) covering three districts, Dehradun, Haridwar and Pauri of Garhwal Himalaya (Figure 
Table 1. Description of the research sites.

\begin{tabular}{|c|c|c|c|c|c|}
\hline SN. & $\begin{array}{l}\text { Sites } \\
\text { Districts }\end{array}$ & Climatic/habitat variables* & Geographical location & Soil type & Localities of sampling \\
\hline 1. & $\begin{array}{l}\text { Laldhang } \\
\text { Haridwar }\end{array}$ & $\begin{array}{l}\text { Mean temp }\left({ }^{\circ} \mathrm{C}\right)=24.1 \\
\text { Rain fall }(\mathrm{cm})=13.0 \\
\text { Relative humidity }(\%)=86.8 \\
\text { Light intensity }(\text { Lux })=895\end{array}$ & $\begin{array}{l}\text { Longitude: } 78^{0} 30^{\prime} \mathrm{E} \\
\text { Latitude: } 29^{0} 81^{\prime} \mathrm{N} \\
\text { Altitude: } 342 \mathrm{~m} \text { asl } \\
\text { Situated at the foot-hills of } \\
\text { Western Himalaya at the } \\
\text { banks of river Rawasan }\end{array}$ & Loam and red & $\begin{array}{l}\text { Mango garden, Bus } \\
\text { Stop, Rawasan river } \\
\text { road, Chandi Devi } \\
\text { Haridwar, Har Ki Pauri } \\
\text { etc. }\end{array}$ \\
\hline 2. & $\begin{array}{l}\text { Dakpatthar } \\
\text { Dehradun }\end{array}$ & $\begin{array}{l}\text { Mean temp }\left({ }^{\circ} \mathrm{C}\right)=20.8 \\
\text { Rain fall }(\mathrm{cm})=18.3 \\
\text { Relative humidity }(\%)=91.0 \\
\text { Light intensity }(\text { Lux })=685\end{array}$ & $\begin{array}{l}\text { Longitude: } 77^{0} 75^{\prime} \mathrm{E} \\
\text { Latitude: } 30^{\circ} 47^{\prime} \mathrm{N} \\
\text { Altitude: } 895 \mathrm{~m} \text { asl } \\
\text { Situated at the Siwalik } \\
\text { range of Western Himalaya } \\
\text { at the banks of river } \\
\text { Yamuna }\end{array}$ & $\begin{array}{l}\text { Sandy, loam clay, } \\
\text { silt, } \\
\text { conglomerate, } \\
\text { calcareous tuffs } \\
\text { gravel and } \\
\text { alluvial }\end{array}$ & $\begin{array}{l}\text { Guptsahasradhara, } \\
\text { Drona cave, } \\
\text { Sahastradhara Shiva } \\
\text { temple, etc. }\end{array}$ \\
\hline 3. & $\begin{array}{l}\text { Rishikesh } \\
\text { Dehradun }\end{array}$ & $\begin{array}{l}\text { Mean temp }\left({ }^{\circ} \mathrm{C}\right)=21.1 \\
\text { Rain fall }(\mathrm{cm})=15.0 \\
\text { Relative humidity }(\%)=88.1 \\
\text { Light intensity }(\text { Lux })=730\end{array}$ & $\begin{array}{l}\text { Longitude: } 78^{0} 28^{\prime} \mathrm{E} \\
\text { Latitude: } 30^{0} 10^{\prime} \mathrm{N} \\
\text { Altitude: } 356 \mathrm{~m} \text { asl } \\
\text { Situated at the inner range } \\
\text { of Siwalik Himalaya at the } \\
\text { basin of river Ganga }\end{array}$ & $\begin{array}{l}\text { Loam containing } \\
\text { gravel or alluvial } \\
\text { type, clay humus, } \\
\text { sandy, boulders } \\
\text { and sand stones }\end{array}$ & $\begin{array}{l}\text { Kalidhal, Luxman } \\
\text { Jhoola }\end{array}$ \\
\hline 4. & $\begin{array}{l}\text { Kotdwar } \\
\text { Pauri- } \\
\text { Garhwal }\end{array}$ & $\begin{array}{l}\text { Mean temp }\left({ }^{\circ} \mathrm{C}\right)=23.2 \\
\text { Rain fall }(\mathrm{cm})=12.4 \\
\text { Relative humidity }(\%)=86.6 \\
\text { Light intensity }(\text { Lux })=865\end{array}$ & $\begin{array}{l}\text { Longitude: } 78^{0} 38 \mathrm{E} \\
\text { Latitude: } 29^{0} 46^{\prime} \mathrm{N} \\
\text { Altitude: } 376 \mathrm{~m} \text { asl } \\
\text { Situated at the foot-hills of } \\
\text { Garhwal Himalaya at the } \\
\text { banks of river Khoh }\end{array}$ & $\begin{array}{l}\text { Loam, conglo- } \\
\text { merate sand } \\
\text { stones, grits, } \\
\text { pseudo conglo- } \\
\text { merate, gravel, } \\
\text { clay and alluvial }\end{array}$ & $\begin{array}{l}\text { Durga Devi temple, } \\
\text { Dugadda, Inspection } \\
\text { House }\end{array}$ \\
\hline
\end{tabular}

*Mean values of the temperature and relative humidity were measured with the help of Thermohygrograph. Up and down peaks sketched by the equipment on the paper represent higher and lower limits of temperature and humidity. The intensity of light was directly taken by digital Lux meter. The values of sun shine were measured three times a day, i.e. morning, noon and evening and their mean has been used in the table.

1). The study sites comprise a group of low-lying hills with rivers, springs, streams, swamps, ravines, rivulets, pits and ponds situated at a longitude of $77^{\circ} 75^{\prime}$ to $78^{\circ} 38^{\prime} \mathrm{E}$ and latitude $29^{\circ} 46^{\prime}$ to $30^{\circ} 47^{\prime} \mathrm{N}$. The elevation of different sites ranges between 300-900 $\mathrm{m}$ above mean sea level ( $\mathrm{m}$ asl). The study sites have sub-tropical climate with mean temperature ranging from $20.8^{\circ} \mathrm{C}$ (Dakpatthar) to $24.1^{\circ} \mathrm{C}$ (Laldhang) and annual rain fall from $12.4 \mathrm{~cm}$ (Kotdwar) to $18.3 \mathrm{~cm}$ (Dakpatthar) (Table 1).

\section{SAMPLING}

Cyanobacterial samples, for various taxonomic studies, were collected from all research sites in different seasons, i.e. summer, winter and rainy in the year 2002. The samples included aquatic, terrestrial, epilithic, epipelic, endophytic and epiphytic cyanobacterial forms. However, the present paper deals with the studies conducted only for the epiphytic forms of the cyanobacteria. The samples with visible growth of blue-green algae were collected into sterile plastic bottles. On returning to the laboratory, they were washed thoroughly with water, transferred to air-tight glass containers, and preserved in $4 \%$ formalin solution. The micro-slides were prepared from the fixed as well as fresh algal materials for microscopic observations. Temporary glycerin mounts prepared for the study were converted to semi-permanent slides by sealing the joints of slide and cover slips by nail polish with the help of slide ringing table.

\section{IDENTIFICATION OF THE CYANOBACTERIA}

The identifications were made by following Desikachary (1959) and Anand (1989), and also by the consultation of other pertinent literature (Kumar 1985; Mann 2000; Stal 2000) in the field. The cyanobacterial specimens were identified at the level of class, order, family, genus and species. Morphological variations of different specimens were also analyzed. 
Table 2. Distribution of epiphytic cyanobacteria in the foot-hills of Garhwal Himalaya.

\begin{tabular}{|c|c|c|c|c|c|}
\hline S.No. & Taxa & Dakpatthar & Kotdwar & Rishikesh & Laldhang \\
\hline 1 & Microcystis viridis & - & - & + & - \\
\hline 2 & Microcystis aeruginosa & + & - & - & - \\
\hline 3 & Microcystis robustav. minor var. nov. & - & - & + & - \\
\hline 4 & Microcystis lamelliformis & - & - & + & - \\
\hline 5 & Chroococcus turgidus var. solitarius & - & - & + & - \\
\hline 6 & Chroococcus indicus & + & - & - & - \\
\hline 7 & Chroococcus minutus & - & - & - & + \\
\hline 8 & Chroococcus hansgirgi & + & - & + & - \\
\hline 9 & Chroococcus cohaerens & + & - & - & + \\
\hline 10 & Chroococcus minor & - & + & - & + \\
\hline 11 & Aphanocapsa koordersi & - & - & - & + \\
\hline 12 & Aphanocapsa biformis & + & + & + & + \\
\hline 13 & Aphanocapsa grevillei & - & - & + & - \\
\hline 14 & Aphanocapsa pulchra & + & - & + & + \\
\hline 15 & Synechocystis aquatilis & - & + & - & + \\
\hline 16 & Merismopedia tenuissima & - & - & + & - \\
\hline 17 & Xenococcus acervatus & - & + & - & - \\
\hline 18 & Spirulina subsalsa & - & - & - & + \\
\hline 19 & Spirulina gigantean & - & - & + & - \\
\hline 20 & Oscillatoria foreaui & - & + & - & - \\
\hline 21 & Oscillatoria tenuis & - & + & + & - \\
\hline 22 & Phormidium fragile & + & + & - & - \\
\hline 23 & Lyngbya mesotrica & - & - & - & + \\
\hline 24 & Lyngbya kuetzingii & + & + & - & - \\
\hline 25 & Lyngbya spirulinoides & - & - & + & - \\
\hline 26 & Lyngbya dendrobia & + & + & - & - \\
\hline 27 & Aulosira pseudoramosa & - & - & + & - \\
\hline 28 & Aulosira ferttillissima var. tenuis & - & + & + & - \\
\hline 29 & Plectonema hansgirgi & - & - & + & - \\
\hline 30 & Scytonema malaviyaensis & + & - & + & + \\
\hline 31 & Microchaete grisea var. brevis & + & + & + & - \\
\hline 32 & Microchaete elongate & - & - & + & - \\
\hline 33 & Calothrix parietina & + & + & + & - \\
\hline 34 & Calothrix fusca & - & + & + & - \\
\hline 35 & Calothrix scytonemicola & - & - & + & + \\
\hline 36 & Calothrix braunii & - & - & + & - \\
\hline 37 & Rivularia dura & - & - & + & - \\
\hline 38 & Gleotrichia pilgeri & - & + & + & + \\
\hline \multirow[t]{2}{*}{39} & Gleotrichia raciborskii var. bombayense & - & - & + & - \\
\hline & Site-wise number of species & 12 & 14 & 25 & 12 \\
\hline
\end{tabular}


Table 3. Taxonomic categorization of cyanobacteria encountered in the foot-hills of Garhwal Himalaya.

\begin{tabular}{|c|c|c|c|c|c|}
\hline \multirow[t]{2}{*}{ Orders } & \multirow[t]{2}{*}{ Families } & \multirow[t]{2}{*}{ Genera } & \multicolumn{3}{|c|}{ Number of species } \\
\hline & & & Total & Heterocystous forms & Non-heterocystous forms \\
\hline \multirow[t]{6}{*}{ Chroococcales } & Chroococcaceae & Microcystis & 4 & - & 4 \\
\hline & & Chroococcus & 6 & - & 6 \\
\hline & & Aphanocapsa & 4 & - & 4 \\
\hline & & Synechocystis & 1 & - & 1 \\
\hline & & Merismopedia & 1 & - & 1 \\
\hline & Hyellaceae & Xenococcus & 1 & - & 1 \\
\hline \multirow[t]{11}{*}{ Nostocales } & Oscillatoriaceae & Spirulina & 2 & - & 2 \\
\hline & & Oscillatoria & 2 & - & 2 \\
\hline & & Phormidium & 1 & - & 1 \\
\hline & & Lyngbya & 4 & - & 4 \\
\hline & Nostococcaceae & Aulosira & 2 & 2 & - \\
\hline & & Plectonema & 1 & - & 1 \\
\hline & Scytonemataceae & Scytonema & 1 & 1 & - \\
\hline & & Microchaete & 2 & 2 & - \\
\hline & Microchaetaceae & Calothrix & 4 & 4 & - \\
\hline & Rivulariaceae & Rivularia & 1 & 1 & - \\
\hline & & Gleotrichia & 2 & 2 & - \\
\hline Total & & & 39 & 12 & 27 \\
\hline
\end{tabular}

\section{NUMERICAL METHODS}

Principal component analysis (PCA), an indirect gradient ordination method, was used to summarize the compositional differences among the research sites based on the abundance (presence-absence) on epiphytic cyanobacterial flora, using multivar option in PAST 1.92 (Hammer et al. 2001; Hall 2005). Cluster analysis (using Euclidean distance method) of the different cyanobacterial flora with reference to their occurrence in various sites has also been done by using the same software.

\section{Results}

\section{DIVERSITY OF EPIPHYTIC CYANOBACTERIA}

Cyanobacterial flora of the study area was represented by 39 species belonging to 17 genera and 7 families of 2 orders, namely Chroococcales and Nostocales (Table 2 and 3; Appendix 1). The members of Chroococcales and Nostocales represent whole the epiphytic cyanobacterial flora of the region by having 17 and 22 species, respectively. All the species cover a wide range of habitats i.e. they were collected from the roots and leaves of the grasses as well from the bark of the trees (Figures 2 and 3). Site-wise details of various taxa recorded in the present study are presented in Table 2. Whole of the species belonging to Chroococcales were nonheterocystous, while Nostocales represented 10 nonheterocystous and 12 heterocystous species (Table 3). Chroococcus (with 6 species), Microcystis (4), Lyngbya (4), Aphanocapsa (4) and Calothrix (4) were the best representative genera of this region with higher number of epiphytic taxa. These were followed by Oscillatoria (2 species), Spirulina (2), Aulosira (2), Michrochaete (2) and Gloeotrichia (2). Other genera included Synechocystis (with 1 species), Merismopedia (1), Xenococcus (1), Phormidium (1), Plectonema (1), Scytonema (1) and Rivularia (1). Highest number of species (25) was reported from Rishikesh, followed by Kotdwar with 14 species and Laldhang and Dakpatthar each with 12 species.

\section{MULTIVARIATE ANALYSIS}

PCA analysis required 3 components (axis) to account for $100 \%$ variation in the data set. The first two axes of PCA cumulatively explained $78.50 \%$ of variance (individually the first axis explained $48.13 \%$ and the second axis explained $30.37 \%$ of variance) (Figure 4 ). While Dakpatthar and 


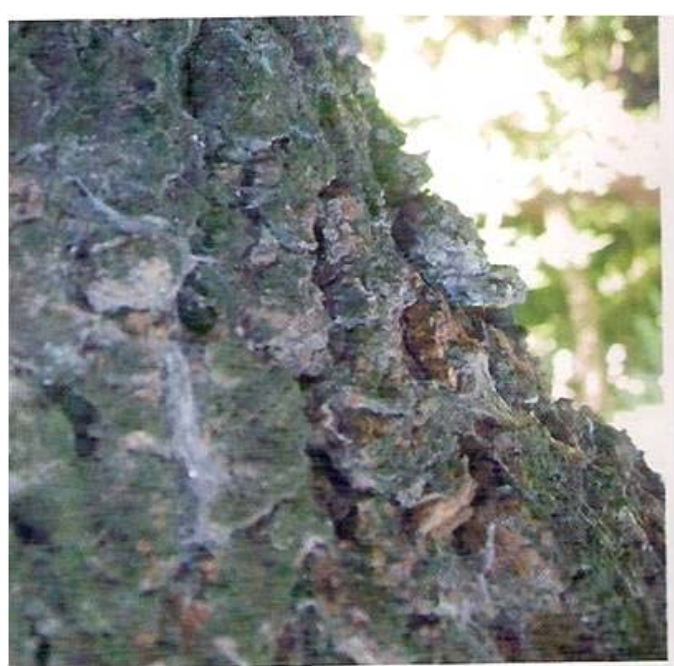

A

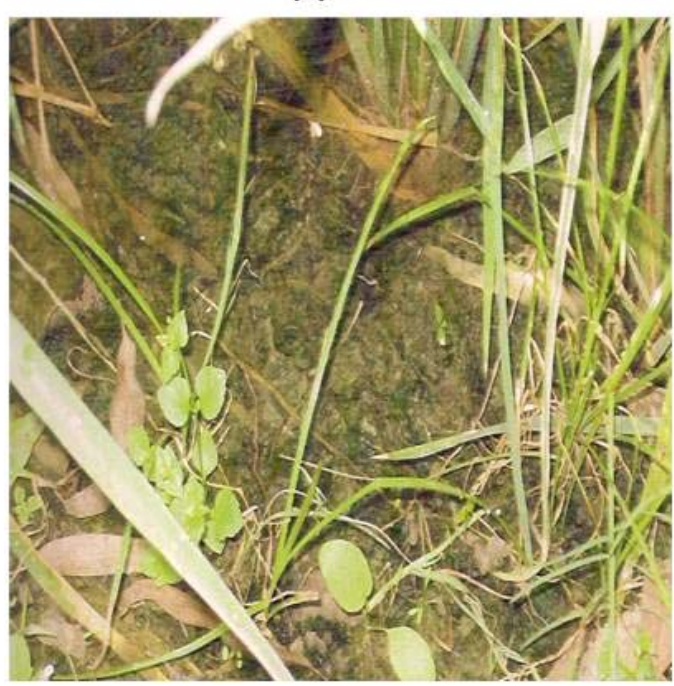

C

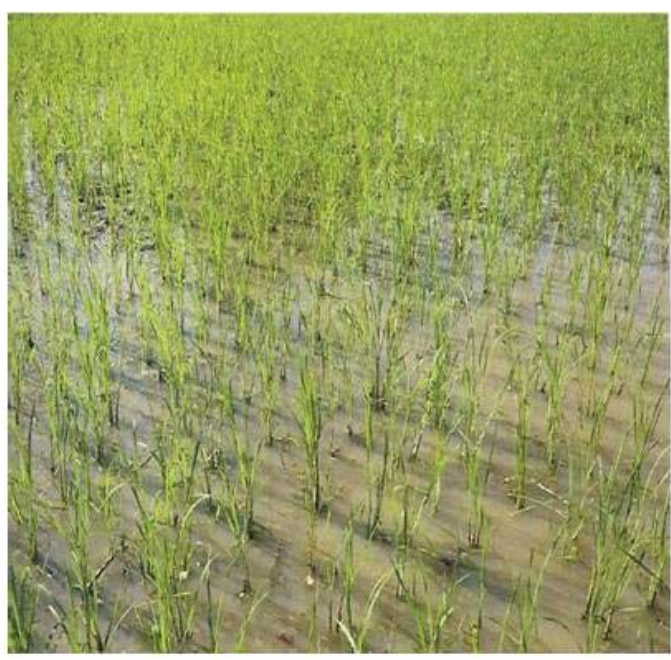

B

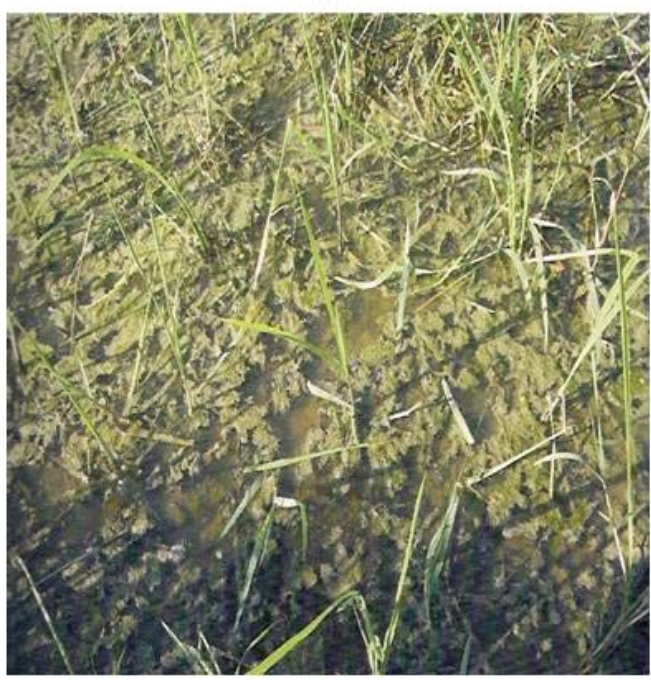

D

Figure 2. Photographs of some variable habitats of some epiphytic cyanobacteria in the foot-hills of Garhwal Himalaya, Uttarakhand, India. (A) Copious growth of cyanobacteria on moist mango tree bark at Dugadda, (B) cyanobacteria occurring on the leaves of paddy plants at Kotdwar, (C) cyanobacterial forms attached to the roots and the leaves of the plants growing near water at Rishikesh, (D) luxurious growth of cyanobacteria on the leaves of grasses growing in a ditch at Dakpatthar.

Kotdwar sites were separated towards the negative end of axis 1 and positive end of axis 2 in PCA ordination space, Rishikesh was separated toward positive end and Laldhang towards negative end of PCA axis 1 (Figure 4).

The cluster analysis revealed two groups (Figure 5): (i) CLUSTER - I with 9 species (Aphanocapsa koordersi, Chroococcus cohaerens, Chroococcus minor, Chroococcus minutes, Lyngbya mesotrica, Oscillatoria foreaui, Spirulina subsalsa, Synechocystis aquatilis and Xenococcus acervatus), and (ii) CLUSTER - II with 30 species (Aphanocapsa biformis, Aphanocapsa grevillei, Aphanocapsa pulchra, Aulosira ferttillissima var. tenuis, Aulosira pseudoramosa, Calothrix braunii, Calothrix fusca, Calothrix parietina, Calothrix scytonemicola, Chroococcus hansgirgi, Chroococcus indicus, Chroococcus turgidus var. solitarius, Gleotrichia pilgeri, Gleotrichia raciborskii var. bombayense, 


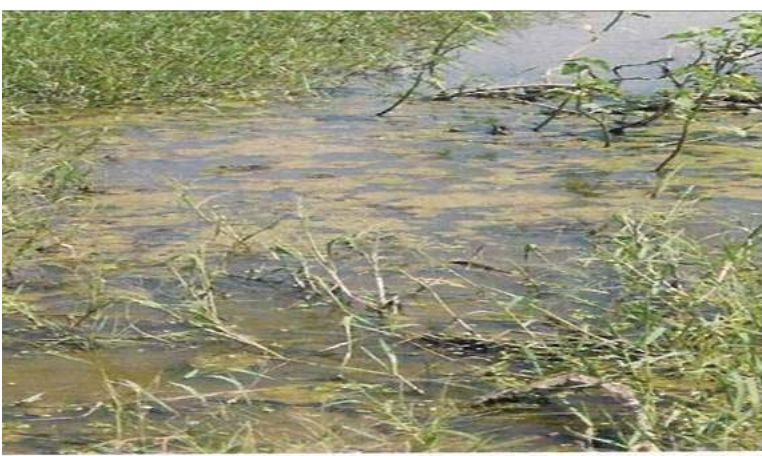

A

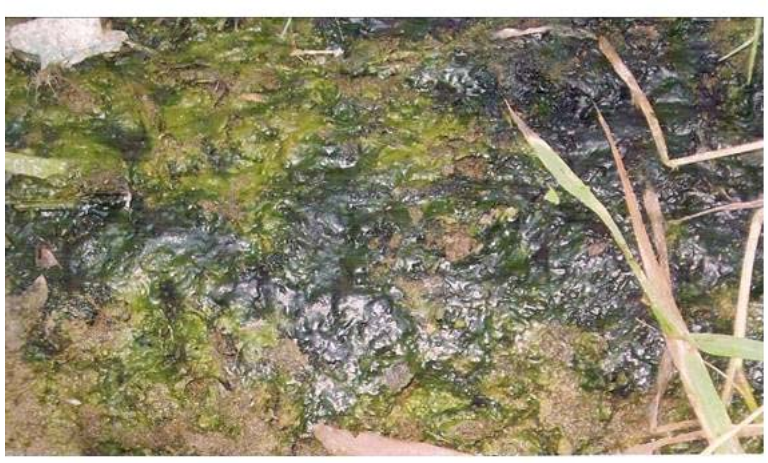

B

Figure 3. Photographs of some variable habitats of some epiphytic cyanobacteria in the foot-hills of Garhwal Himalaya, Uttarakhand, India. (A) Various cyanobacterial forms attached to the stems of higher plants and the leaves of the grasses at Kotdwar, (B) algal growth in the vicinity of grasses as well as on their leaves.

Lyngbya dendrobia, Lyngbya kuetzingii, Lyngbya spirulinoides, Merismopedia tenuissima, Microchaete elongate, Microchaete grisea var. brevis, Microcystis aeruginosa, Microcystis lamelliformis, Microcystis robusta var. minor var. nov., Microcystis viridis, Oscillatoria tenuis, Phormidium fragile, Plectonema hansgirgi, Rivularia dura, Scytonema malaviyaensis and Spirulina gigantean).

\section{Discussion}

Taxonomic analysis of the species shows that the foot-hills of Garhwal Himalaya are rich in epiphytic cyanobacterial diversity. Present study represents 39 cyanobacterial species occurring as epiphytes at various research sites (Table 2). The foot-hills of the Himalayan range provide higher temperature, high moisture and high relative humidity as compared to the arctic zones (Chaudhary 2004). The higher temperature and moisture conditions coupled with moderate light intensity in the study area favor the growth and development of algae belonging to various classes. Particularly, the climate of Rishikesh favors the growth of the epiphytic cyanobacterial forms. Similar results of higher temperature $\left(24-30^{\circ} \mathrm{C}\right)$ and moisture contents (80-94\%) favoring the growth of cyanobacteria have been reported by Kumar (2002), Chaudhary and Kumar (2005), and Khare and Kumar (2009) in the foot hills of Garhwal and Kumaon regions of Uttarakhand, India.

As suggested by PCA (Figure 4), the research sites Dakpatthar and Kotdwar show similar composition of cyanobacterial flora as these sites share six common taxa (i.e. Aphanocapsa biformis, Phormidium fragile, Lyngbya kuetzingii, Lyngbya dendrobia, Microchaete grisea var. brevis and Calothrix parietina); whereas Rishikesh was mapped distinctly in PCA space due to its exclusive eleven taxa that were present only at this site (i.e. Microcystis robusta var. minor var. nov, Microcystis lamelliformis, Chroococcus turgidus var. solitaries, Merismopedia tenuissima, Spirulina gigantean, Aulosira pseudoramosa, Plectonema hansgirgi, Calotrix scytonemicola, Calotrix braunii, Rivularia dura, and Gleotrichia raciborskii var. bombayense). Further, the site Laldhang, due to its different assemblage of cyanobacterial flora, had four exclusive species (i.e. Chroococcus minutes, Aphanocapsa koordersi, Spirulina susalsai, Lyngbya mesotrica). The specimen Microcystis robusta var. minor (var. novo) differs from the type by having smaller cells with spherical to ellipsoidal shape (Appendix 1). Hence warrants as a new variety minor of Microcystis robusta.

Cyanobacteria have been known for augmentation of organic nitrogen to diverse ecological habitats by converting molecular nitrogen into ammonium compounds with the help of enzyme 'nitrogenase complex' (Adams and Duggan 1999). Subsequently, they support the proliferation of eukaryotes and other non-nitrogen fixers in different ecological condition as free living, epiphytic and endophytic forms. Nitrogen contribution to rice fields by epiphytic cyanobacteria associated with Chara is well documented by Ariosa et al. (2004). The present study concludes that variation in epiphytic cyanobacterial diversity might be compared to physicochemical properties of soil and climatic conditions along altitudes. The enumeration of epiphytic cyanobacterial diversity might provide some basic understanding of 


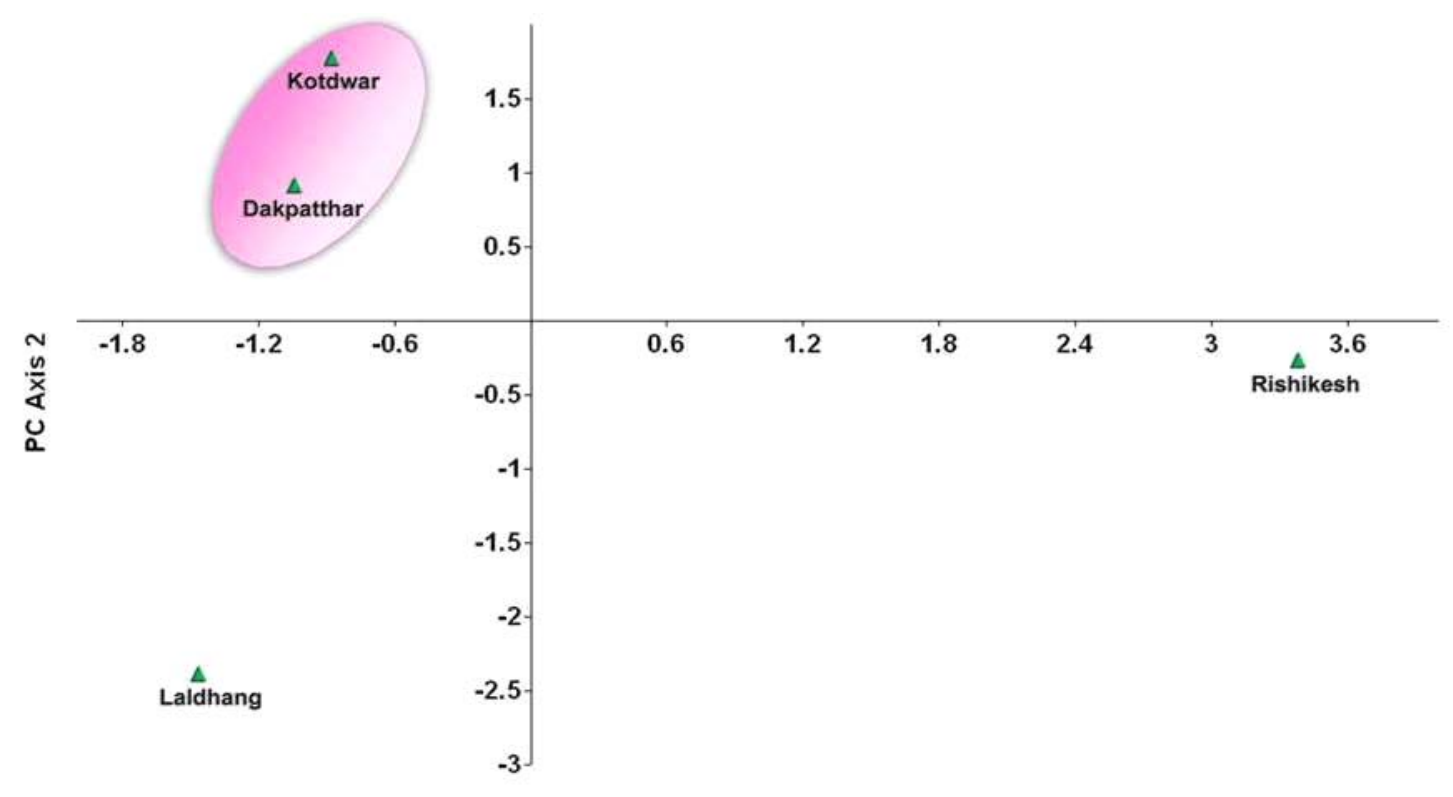

PC Axis 1

Figure 4. PCA ordination plot of four study sites: data showing compositional difference between sites, based on the abundance data of cyanobacterial flora of the studied sites.

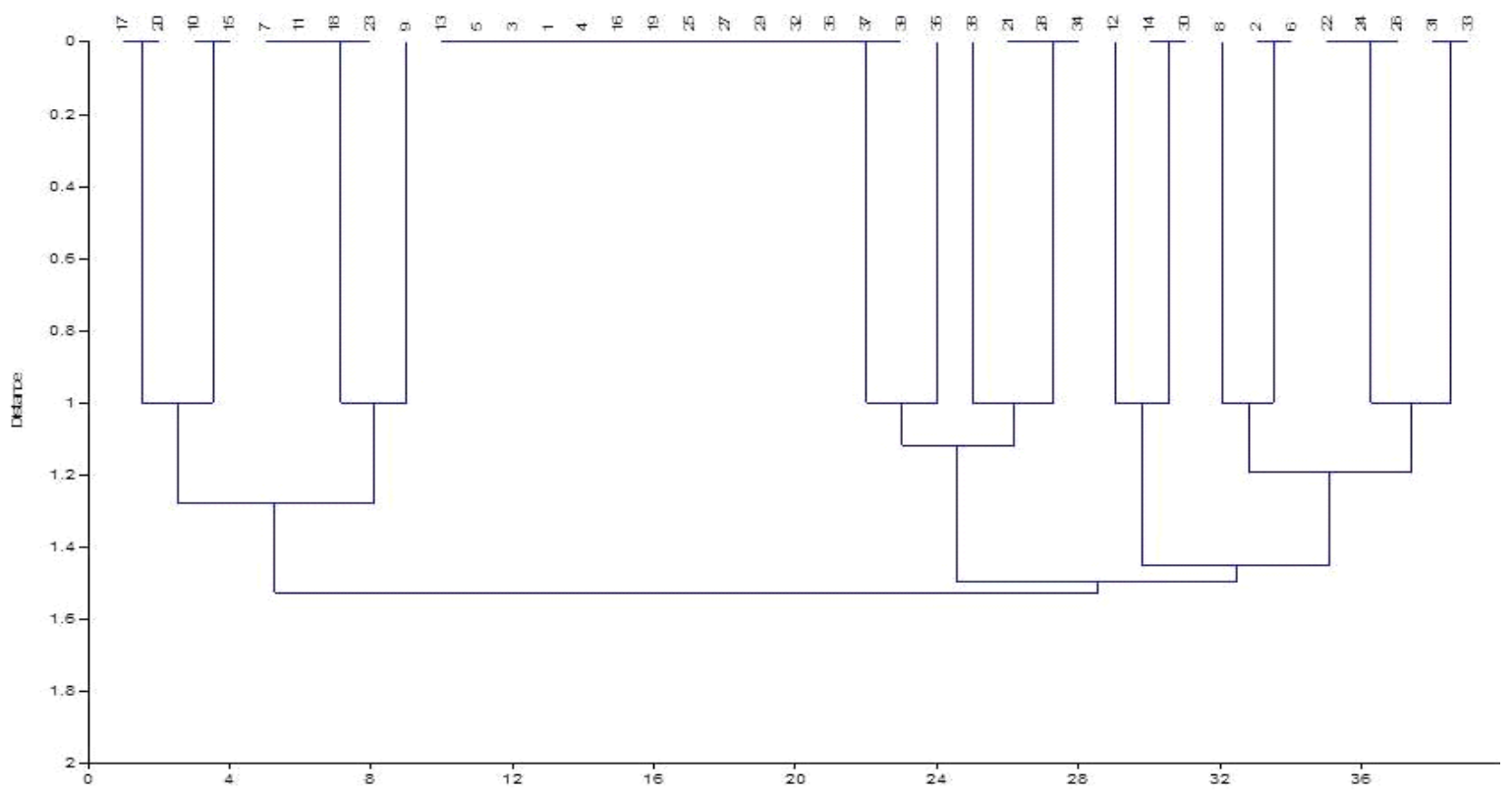

Figure 5. Cluster analysis of the different cyanobacterial flora with reference to their occurrence in various sites. 
physiological and molecular adaptation and extent of nitrogen and other contribution to different plants.

\section{Acknowledgements}

The authors are thankful to the University Grants Commission, New Delhi and UCOST, Dehradun for financial assistance; and the Principals of Sahu Jain P.G. College, Najibabad and Govt. P.G. Autonomous College, Rishikesh for extending their all round support.

\section{References}

Adams D.G. and Duggan P.S. 1999. Heterocyst and akinete differentiation in cyanobacteria. New Phytologist 144: 3-33.

Anand N. 1989. Hand Book of Blue-green Algae. Bishen Singh and Mahenderpal Singh Publ., Dehradun, India.

Ariosa Y., Quesada A., Aburto J., Carrasco D. and Carreres R. 2004. Epiphytic cyanobacteria on Chara vulgaris are the main contributors to $\mathrm{N}_{2}$ fixation in rice fields. Applied and Environmental Microbiology 70: 5391-5397.

Chaudhary M.K. 2004. An Ecological and Taxonomic Investigation of the Cyanophycean Flora of the Foot-Hills of Garhwal Himalayas of Uttaranchal (India). Ph.D. Thesis, MJP Rohilkhand University, Bareilly, Uttar Pradesh, India.

Chaudhary M.K. and Kumar M. 2005. Epiphytic Chroococcales of freshwater bodies of Rishikesh (Dehradun) Uttarakhand. In: National Seminar on Sustainable Water Management (A. Kumar, ed.), pp. 233-242. Dr S.P. Mukerjee Govt. Degree College, Phaphamau, Allahabad, Uttar Pradesh, India.

Desikachary T.V. 1959. Cyanophyta. ICAR Publcation, New Delhi, India.

Fogg G.E., Stewart W.D.P., Fay P. and Walsby A.E. 1973. The Blue-Green Algae. Academic Press, London, UK.

Fong P., Smith T.B. and Wartian M.J. 2006. Epiphytic cyanobacteria maintain shifts to macroalgal dominance on coral reefs following ENSO disturbance. Ecology 87: 1162-1168.

Hall A. 2005. The Environmental Gradients and Plant Communities of Bergen Swamp, NY, USA. MS Thesis,
Rochester Institute of Technology, Rochester, New York, USA. [Online] URL: https://ritdml.rit.edu/bitstream/handle/ 1850/1121/AHallThesis2005.pdf? sequence $=8$.

Hammer Ø, Harper D.A.T. and Ryan P.D. 2001. PAST: paleontological statistics software package for education and data analysis. Palaentologia Electonica 4(1):9 [online] URL: http://palaeo-electronica.org/2001_1/past/issue1_01.htm.

Khare A. and Kumar M. 2009. Habitat-wise diversity of cyanobacteria in the sub-Himalayan belt of Kumaon region. In: National Seminar on the Present Status of Medicinal Plants: Aspects and Prospects (C.P. Shukla and B.L. Prajapati, eds.), pp. 158-161. Mahapandit R.S. Shoudh Sansthan evam Adhayayan Kendra, varanasi, Uttar Pradesh, India.

Kumar H.D. 1962. Apparent genetic recombination in a bluegreen alga. Nature 196: 1121-1122.

Kumar M. 1985. Cyanophyceae of Bijnor. M.Sc. Thesis, CCS University, Meerut, Uttar Pradesh, India.

Kumar M. 2002. Biodiversity of Cyanophyceae of the SubHimalayan Belt. Final Technical Report, University Grant Commission, New Delhi, India.

Mann N.H. 2000. Detecting the environment. In: The Ecology of Cyanobacteria (B.A. Whitton and M. Potts, eds.), pp. 367-395. Kluwer Academic Publishers, Netherlands.

Robarts R.D. and Zohary T. 1987. Temperature effects on photosynthetic capacity, respiration and growth rates of bloom forming cyanobacteria. New Zealand Journal of Marine and Freshwater Research 21: 379-399.

Schopf J.W. and Packer B.M. 1987. Early archean (3.3-billion to 3.5-billion-years-old) microfossils from Warsanoona group, Australia. Science 237: 70-73.

Schopf J.W. and Walter M.R. 1982. Origin and early evolution of cyanobacteria: the geological evidence. In: The Biology of Cyanobacteria (N.G. Carr and B.A. Whitton, eds.), pp 543-564. Blackwell Scientific Publications, Oxford, UK.

Stal L.J. 2000. Cyanobacterial mats and stromatolites. In: The Ecology of Cyanobacteria (B.A. Whitton and M. Potts, eds.), pp. 61-120. Kluwer Academic Publishers, Netherlands.

Van den Hoek C., Mann D.G. and Jahns H.M. 1993. Algae: an Introduction to Phycology, $2^{\text {nd }}$ ed. Cambridge University Press, Cambridge, UK.

Williams S.K., Kempton J., Wilde S.B. and Lewitus A. 2007. A novel epiphytic cyanobacterium associated with reservoirs affected by avian vacuolar myelinopathy. Harmful Algae 6: 343-353. 


\section{Appendix 1}

\section{SYSTEMATIC ENUMERATION OF THE SPECIES}

Letters $\mathrm{R}, \mathrm{S}$ and $\mathrm{W}$ in accession number represent rainy, summer and winter seasons, respectively. The details of a taxon including the measurements are the specific characters of a genus. The camera lucida drawings and microphotographs of some important epiphytic cyanobacteria have been placed in Figures 6-9.

1. Microcystis viridis (A. Br.) Lemm: Accession No. W-10; Sampling time: February 2002. Colony diameter 40.0-41.3 $\mu$, cell diameter 3.5-7.0 $\mu$, cell length 5.5-6.5 $\mu$. Growing on an old stem submerged in a ditch at Kalidhal, Rishikesh.

2. Microcystis aeruginosa Kütz.: Accession No. W-16; Sampling time: February 2002. Cell diameter 3.0-4.5 $\mu$. Attached to the leaves of Selaginella near Shiva Temple water fall, Guptsahastradhara, Dakpatthar.

3. Microcystis robusta var. minor (var. novo): Accession No. R29; Sampling time: August 2002. Colony size 44.0-46.0 $\mu$, Cell diameter 3.4-4.2 $\mu$. Attached to the decaying roots floating over water in rivolut, Kalidhal, Rishikesh.

4. Microcystis lamelliformis Holsinger: Accession No. R-17; Sampling time: October 2002. Colony size $(\mathrm{L} \times \mathrm{B})$ : $58.0-61.0 \times$ 33.0-34.0 $\mu$, Cell diameter 3.5-5.0 $\mu$. Attached to a plant flowing in canal water, Rishikesh.

5. Chroococcus turgidus var. solitarius Ghose: Accession No. R02; Sampling time: September 2002. Cell diameter with sheath 10.2-11.8 $\mu$, cell diameter without sheath 5.1-6.8 $\mu$. Attached on moist bark of Calamus forming a dense covering among mosses and lichens at Garunchatti, Laxman Jhula, Rishikesh.

6. Chroococcus indicus Zeller: Accession No. W-18; Sampling time: February 2002. Cell diameter with sheath 6.8-9.0 $\mu$, cell diameter without sheath 6.5-8.5 $\mu$. Attached to the mosses in running water at Dron Temple, Sahastradhara, Dakpatthar.

7. Chroococcus minutus (Kütz.) Näg.: Accession No. W-04; Sampling time: February 2002. Cell diameter with sheath 9.8$11.0 \mu$, cell diameter without sheath 7.2-8.5 $\mu$. Attached to an

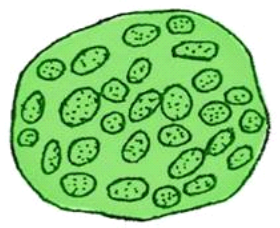

A

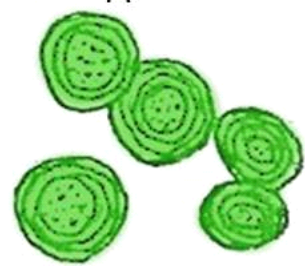

D

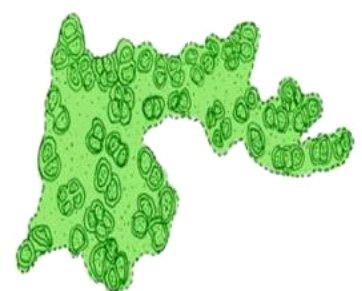

G

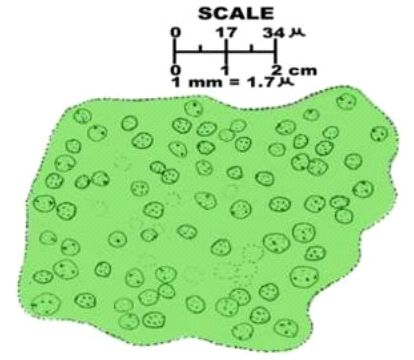

B

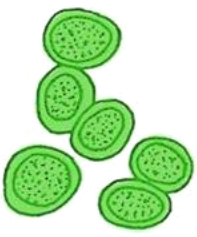

E

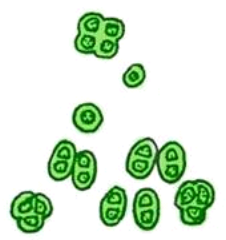

$\mathrm{H}$

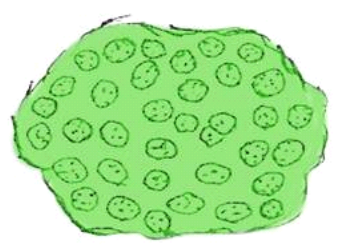

C

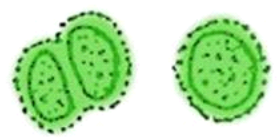

$\mathrm{F}$

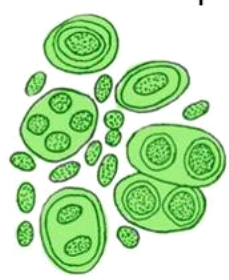

I

Figure 6. Outline diagrams of some epiphytic cyanobacteria from the Sub-Himalayan belt of Garhwal Himalaya, Uttarakhand, India. (A) Microcystis viridis, (B) M. aeruginosa, (C) M. robusta var. minor (var. novo), (D) Chroococcus turgidus var. solitarious, (E) C. indicus, (F) C. minutus, (G) C. cohaerens, (H) C. minor, and (I) Aphanothece bullosa. 


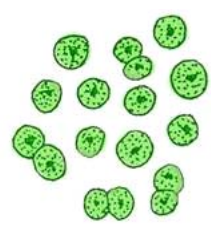

A

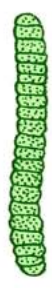

D

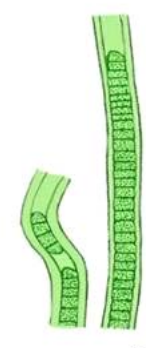

G

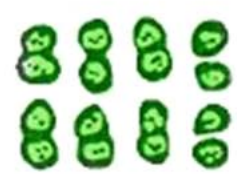

B

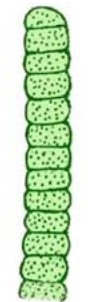

E

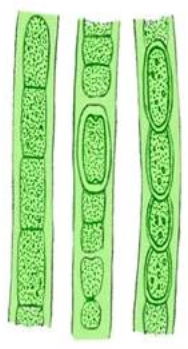

$\mathrm{H}$

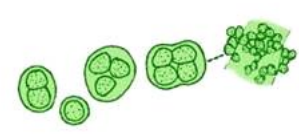

C

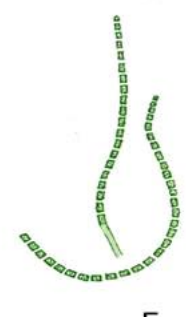

$\mathrm{F}$

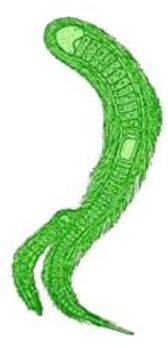

I

Figure 7. Outline diagrams of some epiphytic cyanobacteria from the Sub-Himalayan belt of Garhwal Himalaya, Uttarakhand, India. (A) Synechocystis aqualis, (B) Merismopedia tenuissima, (C) Xenococcus acervatus, (D-E) Oscillatoria tennuis, (F) Phormidium fragile, (G) Lyngbya dendrobia, (H) Aulosira fertilissime var. tenuis, and (I) Calothrix parietina.

old wood piece submerged in a puddle of a mango garden, near Bus Stand, Laldhang.

8. Chroococcus hansgirgi Schmidle: Accession No. R-08 and W-22; Sampling time: September 2002 (Rishikesh) and February 2002 (Dakpatthar). Cell size $(\mathrm{L} \times \mathrm{B})$ 15.6-16.5 × 7.5-12.0 $\mu$. Growing on dead grasses and also on stones submerged in running water, Laxman Jhoola, Rishikesh. Attached with grasses in the form of an algal mass in slow running water of a drain, Sahastradhara, Dakpatthar.

9. Chroococcus cohaerens (Breb.) Näg.: Accession No. W-07 and S-06; Sampling time: February 2002 (Dakpatthar) and June 2002 (Laldhang). Colony diameter 10.2-13.8 $\mu$, cell breadth with sheath 5.0-8.5 $\mu$, cell breadth without sheath 2.0-6.8 $\mu$. Attached to some pteridophytes, Sahastradhara, Dakpatthar. On moist bark of Mangifera indica, Mango garden near Bus Station, Laldhang.

10. Chroococus minor (Kütz.) Näg.: Accession No. R-10, W04; Sampling time: August 2002 (Kotdwar) and Kumar 2002 (Laldhang). Cell breadth without sheath 3.0-4.0 $\mu$. Attached on moist bark of mango tree opposite to inspection House, Dugadda,
Kotdwar. Attached to an old wood piece dipped in a puddle, mango Garden near Bus Station, Laldhang.

11. Aphanocapsa koordersi Storm: Accession No. W-04; Sampling time: February 2002. Cell diameter 1.4-3.1 $\mu$. Attached on a piece of wood submerged in water of a puddle, Mango garden, Bus Station, Laldhang.

12. Aphanocapsa biformis A. Br.: Accession No. R-02, R-40, R12, S-06; Sampling time: September 2002 (Rishikesh), September 2002 (Dakpatthar), August 2002 (Kotdwar) and Jun 2002 (Laldhang) respectively. Cell diameter without sheath 4.3-7.0 $\mu$, cell diameter with sheath 10.7-12.9 $\mu$. Present on moist bark of Calamus, Luxman Jhoola, Rishikesh. Attached on small piece of wood near a waterfall at Sports College, Sahastradnara, Dakpatthar. Growing on moist bark of a mango tree, Gadighat, Kotdwar. Growing on moist bark of mango tree, Mango garden near Bus Stop, Laldhang.

13. Aphanocapsa grevelli (Hass.) Rabenh.: Accession No. S-08; Sampling time: June 2002. Cell diameter 3.7-5.2 $\mu$. Attached on roots of trees in slow running water, Kalidhal, Rishikesh. 


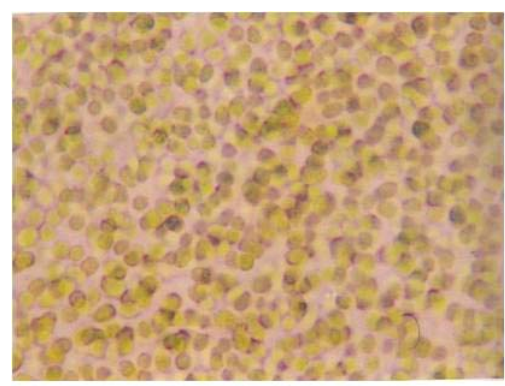

A

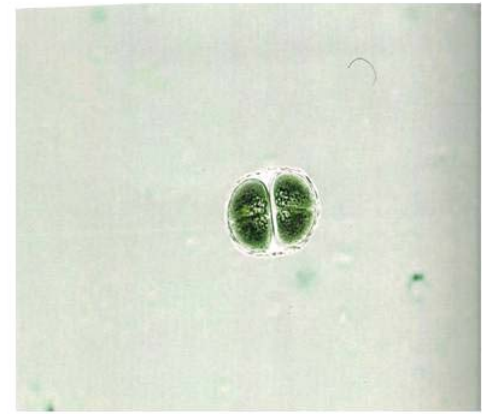

C

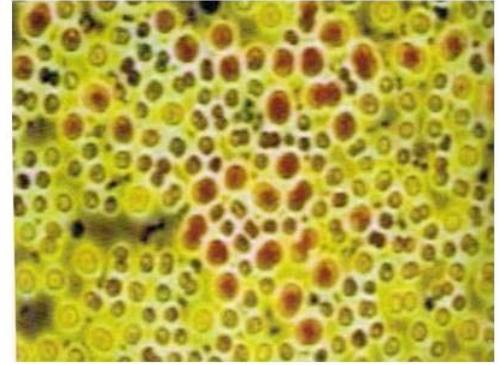

B

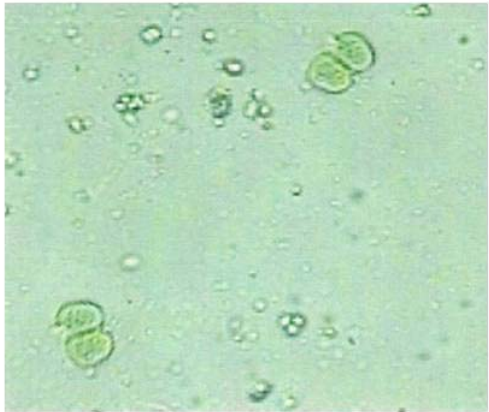

D

Figure 8. Microphotographs of some taxa of epiphytic cyanobacteria from the foot-hills of Garhwal Himalaya, Uttarakhand, India. (A) Microcystis aeruginosa, (B) M. Robusta var. minor (var. novo), (C) Chroococcus turgidus var. solitarious, and (D) Synechocystis aqualis.

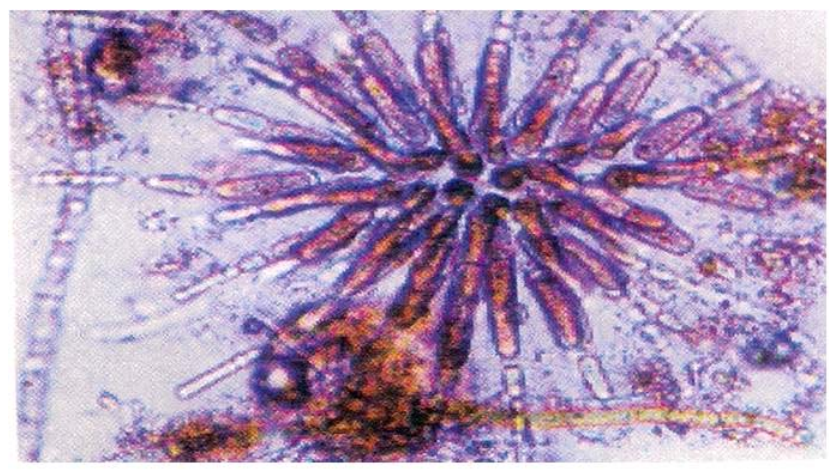

A

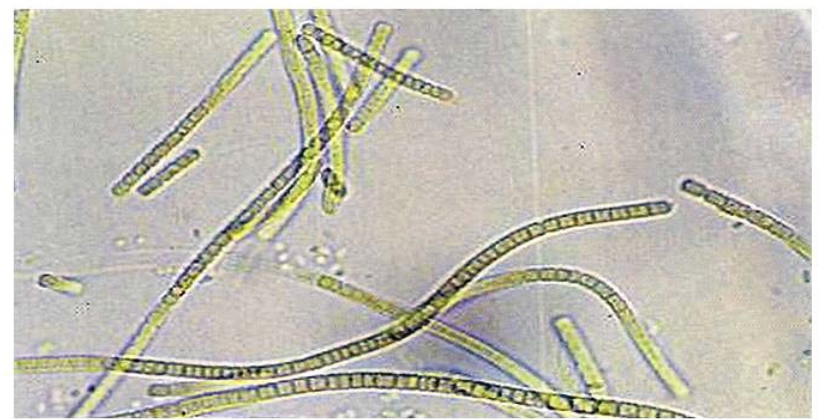

C

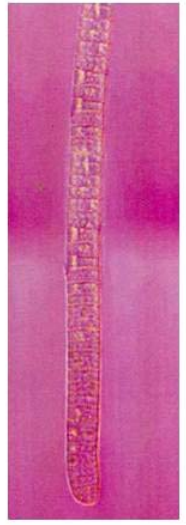

B

Figure 9. Microphotographs of some taxa of epiphytic cyanobacteria from the foot-hills of Garhwal Himalaya, Uttarakhand, India. (A) Calothryx parietina, (B) Phormidium fragile, (C) Oscillatoria tennuis. 
14. Aphanocapsa pulchra (Kütz.) Rabenh.: Accession No. R12, S-12, R-12; Sampling time: October 2002 (Dakpatthar), June 2002 (Rishikesh) and October 2002 (Laldhang). Cell diameter 3.4-4.3 $\mu$. Attached on mosses in a drain, Dakpatthar. Attached on dead plants at the bank of canal, Rishikesh. Attached on pteridophytes near Bus Stand, Laldhang.

15. Synechocystis aquatilis Sauv.: Accession No. S-26; Sampling time: June 2002 (Kotdwar). Cell diameter 5.7-8.5 $\mu$. Growing on a decaying bamboo stem in a stagnant water of a Gaud (river), Kotdwar.

16. Merismopedia tenuissima Lemm.: Accession No. R-26; Sampling time: October 2002. Cell breadth without envelope 2.5-3.4 $\mu$. Attached on stem of a cut tree in running water of a rivulet, Kalidhal, Rishikesh.

17. Xenococcus acervatus Setchell et Gardner: Accession No. W-19; Sampling time: February 2002. Cell breadth 4.5-6.8 $\mu$. Attached on moist wooden log dipped in polluted water at Badrinath road, Dugadda, Kotdwar.

18. Spirulina subsalsa Oerst. ex Gomont: Accession No. W-04; Sampling time: February 2002. Trichome breadth 1.3-1.9 $\mu$, spiral breadth 3.1-4.2 $\mu$, distance between spirals 3.1-5.2 $\mu$. Attached on a piece of wood dipped in a small dirty pond, Mango garden, Bus Station, Laldhang.

19. Spirulina gigantean Schmidle: Accession No. S-10; Sampling time: June 2002. Trichome breadth 3.4-4.0 $\mu$, spiral breadth 9.3-10.4 $\mu$. Attached on tree bark near Bus Stand, Rishikesh.

20. Oscillatoria foreaui Fàemy: Accession No. S-26; Sampling time: June 2002. Trichome breadth 2.5-3.0 $\mu$, cell length 1.4$1.7 \mu$. Attached on dead bamboo stem dipped in stagnant water of Gaud (river), Dugadda, Kotdwar.
21. Oscillatoria tenuis Ag. ex Gomont: Accession No. R-10, R02; Sampling time: August 2002 (Kotdwar) and September 2002 (Rishikesh). Trichome breadth 6.4-14.4 $\mu$, cell length 3.1-6.8 $\mu$. Growing on the moist bark of mango tree at Dak Banglow, Dugadda, Kotdwar. Occurring on the moist bark of mango tree, Rishikesh

22. Phormidium fragile (Meneghini) Gomont: Accession No. W-25, R-09; Sampling time: February 2002 (Dakpatthar) and August 2002 (Kotdwar). Trichome breadth 2.0-3.4 $\mu$, cell length 3.4-4.0 $\mu$. Attached on grass of a street drain, Dakpatthar. Growing on the leaves of a plant in running water of drainage, Gadighat, Kotdwar.

23. Lyngbya mesotricha Skuja: Accession No. R-29; Sampling time: October 2002. Filament breadth 3.5-5.4 $\mu$, trichome breadth 2.7-3.2 $\mu$, cell length 4.9-8.0 $\mu$. Attached on wood under water in a pond, Mango garden near Bus Stop, Laldhang.

24. Lyngbya kuetzingii Schmidle: Accession No. R-19, W-04; Sampling time: October 2002 (Dakpatthar) and February 2002 (Kotdwar). Filament breadth 2.1-3.7 $\mu$, trichome breadth 38.0$63.0 \mu$, cell length $1.5-2.2 \mu$. Attached on pteridophytic plants in running water of Baldi River, Sahastradhara, Dakpatthar. Growing on the algae, mosses and pteridophytes in slow running water at Durga Devi temple, Dugadda, Kotdwar.

25. Lyngbya spirulinoides Gomont: Accession No. S-08; Sampling time: June 2002. Filament breadth 85.0-98.0 $\mu$, trichome breadth 13.7-15.9 $\mu$, cell length 3.8-5.6 $\mu$. Growing on roots of some aquatic plants in running water, Kalidhal, Rishikesh.

26. Lyngbya dendrobia Bruhl et Biswas: Accession No. W-23, R-11; Sampling time: February 2002 (Dakpatthar) and August 2002 (Kotdwar). Filament breadth 10.5-12.2 $\mu$, Sheath thickness 1.5-2.0 $\mu$, trichome breadth 6.7-7.4 $\mu$, cell length 3.4-5.1 $\mu$. 